\title{
Male and Female Breast Cancer - Differences in DNA Ploidy, p21 and p53 Expression Reinforce the Possibility of Distinct Pathways of Oncogenesis
}

\author{
Saudade André António E. Pinto Cátia Laranjeira Manuela Quaresma \\ Jorge Soares \\ Serviço de Anatomia Patológica, Instituto Português de Oncologia de Lisboa Francisco Gentil, E.P.E., \\ Lisboa, Portugal
}

\section{Key Words}

Male/female breast cancer $\cdot$ p21 $\cdot$ p53 $\cdot$ pRb $\cdot$ Ki-67 $\cdot$ Ploidy ent genomic instability and to differences in cell cycle proliferative control, reinforcing the view of somewhat distinct tumour oncogenesis.

Copyright $\odot 2007$ S. Karger AG, Basel

\begin{abstract}
Aim: The purpose of this study was to compare the immunohistochemical profile of cell cycle inhibitors of G1/S phase transition (p21, p53 and pRb), Ki-67 proliferation marker and DNA ploidy in male (MBC) and female breast cancer (FBC). Material and Methods: One hundred patients (50 non-consecutive cases of $F B C$ and an equal number of $M B C$ ) were selected according to homogeneous features regarding age, histological type, tumour grading, nodal status and absence of neoadjuvant therapy. The expression of p21, p53, $\mathrm{pRb}$ and $\mathrm{Ki}-67$ was assessed by immunohistochemistry, and DNA ploidy was analysed by flow cytometry. Correlations between variables were evaluated using the $\chi^{2}$ test. Results: The incidence of DNA aneuploid, p21-positive and p53-negative tumours was significantly higher in $\mathrm{MBC}$ than in $\mathrm{FBC}$; pRb and Ki-67 revealed no statistically significant differences between the two entities. In MBC, high tumour grade correlated with aneuploidy, Ki- 67 and pRb positivity; ploidy and p53 were also associated. In FBC, only ploidy and grade showed a strong correlation. Conclusion: The significant dissimilarities regarding DNA ploidy, p21 and p53 in these quite homogeneous groups of $\mathrm{FBC}$ and $\mathrm{MBC}$ point to differ-
\end{abstract}

\section{Introduction}

The molecular mechanisms underlying breast cancer pathogenesis and their clinical correlation are mostly unknown, both in male and female patients [1-3]. Interactions between cell cycle inhibitors and tumour cell proliferation markers have been reported as critical to clarify relevant aspects of cancer biopathology, but their true role in oncogenesis and tumour progression, as well as in the clinical effects of chemotherapeutic agents, is still unclear [4-6].

The most well-studied gene is p53, which has been implicated in DNA repair and apoptosis in response to DNA damage, as well as in cell cycle regulation, differentiation and angiogenesis; however, many questions about p53 response pathways continue to be unsolved [7]. Its transcriptional regulated $\mathrm{p} 21$ protein, besides being related to cell repair and apoptosis, appears to promote either growth arrest or proliferation in dependence of the cellular context and mediate the activation of the estrogen-

\section{KARGER}

Fax +4161306 1234

E-Mail karger@karger.ch

www.karger.com (c) 2007 S. Karger AG, Basel

$1015-2008 / 07 / 0746-0323 \$ 23.50 / 0$

Accessible online at:

www.karger.com/pat
António E. Pinto, MD

Serviço de Anatomia Patológica, Instituto Português de Oncologia de Lisboa, E.P.E.

Rua Professor Lima Basto

PT-1099-023 Lisboa (Portugal)

Tel./Fax +351 217229 825, E-Mail aepinto@ipolisboa.min-saude.pt 
Table 1. Comparison between $\mathrm{FBC}$ and $\mathrm{MBC}$ - similar clinicopathological characteristics of two groups of 50 patients with invasive ductal carcinoma

\begin{tabular}{|c|c|c|c|c|c|}
\hline \multirow[t]{2}{*}{ Characteristics } & \multicolumn{2}{|c|}{ Female } & \multicolumn{2}{|c|}{ Male } & \multirow[t]{2}{*}{$\mathrm{p}$ value } \\
\hline & $\mathrm{n}$ & $\%$ & $\mathrm{n}$ & $\%$ & \\
\hline Age & & & & & 0.074 \\
\hline$\leq 50$ years & 13 & 26 & 6 & 12 & \\
\hline$>50$ years & 37 & 74 & 44 & 88 & \\
\hline Tumour grading & & & & & 0.829 \\
\hline G1 & 16 & 32 & 15 & 30 & \\
\hline G2/G3 & 34 & 68 & 35 & 70 & \\
\hline Nodal status & & & & & 0.622 \\
\hline Negative & 24 & 48 & 18 & 43 & \\
\hline Positive & 26 & 52 & 24 & 57 & \\
\hline
\end{tabular}

Note that in $8 \mathrm{MBC}$ cases we had no information about nodal status.

signalling pathway in estrogen receptor-negative neoplastic cells $[4,6,8-10]$. The product of the retinoblastoma gene (pRb) is also involved in the cell cycle control, and its expression seems to parallel proliferative activity in breast carcinomas [11]. Furthermore, it has widely known biological and clinical implications of high cell proliferation and DNA aneuploidy in breast cancer, since both were found to be associated with aggressive clinical behaviour $[12,13]$.

The purpose of this study was to compare the immunohistochemical profile of cell cycle inhibitors of G1/S phase transition (p21, p53 and pRb), Ki-67 cell proliferation marker and DNA ploidy between two groups of patients with invasive ductal female (FBC) and male breast cancer (MBC), selected according to relatively homogeneous clinicopathological and therapeutic criteria. All the parameters studied were also correlated within the groups of male and female cancer.

\section{Patients and Methods}

\section{Clinicopathological Data}

The retrospective series of 100 patients investigated included two groups (50 MBC and an equal number of FBC cases) retrieved from the files of the Instituto Português de Oncologia, Lisboa, Portugal. To improve the reliability of the comparative analysis between the two groups, the patients were selected according to homogeneous criteria, namely, the absence of neoadjuvant therapy, the same histological type (invasive ductal carcinomas of no special type - NOS) [14], similar nodal status $(p=0.622)$ evalu- ated according to the pTNM classification [15], and similar tumour grading $(\mathrm{p}=0.829)$, estimated using the Elston and Ellis system [16] (table 1). In MBC, we had no information about nodal involvement in 8 cases, and 17 patients showed cutaneous ulceration at diagnosis (stage III). The age of the patients (mean age in the FBC group was 57.8 years, range $40-81$, and in the MBC group, 63.6 years, range 39-87), although maintaining the usual frequency of $\mathrm{MBC}$ in an older age group compared with FBC, was not statistically different $(\mathrm{p}=0.074)$, reinforcing the homogeneous features of the two study groups (table 1).

The information about therapeutics and age of the patients was obtained from the patients' medical records.

\section{Immunohistochemistry Assays}

Immunocytochemical analyses were performed on formalinfixed paraffin-embedded material using the streptavidin-biotin complex peroxidase technique [17]. Pretreatment procedures included endogenous peroxidase blocking with $3 \%$ hydrogen peroxide in methanol and antigen retrieval using either a pressure cooker (1 min) and $0.01 \mathrm{M}$ sodium citrate buffer, $\mathrm{pH} 6$ (for p53 and Ki-67), or a 750-watt microwave oven (20 min) and a low pH solution (S1699 target retrieval solution, Dako, Glostrup, Denmark) (for p21 and pRb). Primary monoclonal antibodies used comprised anti-p53 clone D07 (Novocastra Laboratories, Newcastle upon Tyne, UK; $30 \mathrm{~min}$, 1:50 dilution, at room temperature), antip21 clone SX118 (Dako; $60 \mathrm{~min}, 1: 25$ dilution, at room temperature), anti-pRb clone Rb1 (Dako; overnight, 1:500 dilution, at $4^{\circ} \mathrm{C}$ ) and anti-Ki-67/7B11 clone (Zymed Laboratories, San Francisco, Calif., USA; 30 min, 1:50 dilution, at room temperature). The StreptABComplex/HRPDuet Mouse/Rabbit system (Dako K0492), which includes secondary biotinylated antibody and streptavidin-biotinylated horseradish peroxidase, was used as amplifier reagent. The chromogen solution (DAB-hydrogen peroxide; Dako K5001) was applied for staining visualization (brown colour), and the counterstaining was performed with Mayer's haematoxylin (blue colour).

Specific staining of nuclear proteins was evaluated by 2 investigators, semiquantitatively, using a 2 -headed microscope. The immunoreactivity of the sample was analysed by counting at least 500 tumour cells. To improve interlaboratory comparison of data, we adopted $10 \%$ as the cut-off point for the staining classification of p21, p53, pRb ( $\leq 10 \% /$ negative vs. $>10 \% /$ positive) and Ki-67 ( $\leq 10 \% /$ low vs. $>10 \% /$ high proliferative tumours).

\section{DNA Flow Cytometry}

In $\mathrm{FBC}$, flow cytometric analysis was performed on representative frozen samples of tumour tissue obtained at surgical resection, according to a previously reported procedure [12]. In MBC, DNA flow cytometry was performed on paraffin-embedded material, according to the method of Hedley et al. [18], with slight modifications. Following the review of haematoxylin and eosinstained slides, the blocks predominantly composed of tumour were selected, and 50 - $\mu$ m-thick representative sections were cut, deparaffinised in xylene and rehydrated in decreasing concentrations of ethanol. Disaggregation was performed enzymatically by treating sections with $0.5 \%$ pepsin $\mathrm{pH} 1.5$ in a water bath at $37^{\circ} \mathrm{C}$ with frequent vortexing. The samples were washed in distilled water and filtered with a $55-\mu \mathrm{m}$ nylon mesh. The following steps included cell counting, nuclei staining with $50 \mu \mathrm{g} / \mathrm{ml}$ propidium iodide (Sigma), treated with $1 \mathrm{mg} / \mathrm{ml}$ ribonuclease in phosphate- 
buffered saline, $0.05 \%$ NP40 non-ionic detergent (Sigma) (overnight at $4^{\circ} \mathrm{C}$, in the dark), filtration, and finally, flow cytometer analysis. Nuclear DNA ploidy was evaluated on an Epics Profile II flow cytometer (Coulter Electronics, Hialeah, Fla., USA). Fluorescent microbeads were used for daily calibration of the instrument (Flow-Check Fluorospheres, Beckman-Coulter). DNA histograms were analysed using the Multicycle program (Phoenix Flow Systems, San Diego, Calif., USA), which includes a multiple option cell cycle fitting that automatically determines the DNA index. The tumours were classified dichotomically (diploid vs. aneuploid) according to the DNA ploidy pattern. On histograms obtained from paraffin-embedded tissue, the first peak observed was assumed as the G0/G1 diploid population. Histograms with a coefficient of variation $>6 \%$ and/or a high percentage $(>20 \%)$ of aggregates and debris were excluded from the study.

\section{Statistical Analysis}

Correlations between variables were assessed using the $\chi^{2}$ test and Fisher's exact test when appropriate. In order to evaluate homogeneous groups of $\mathrm{FBC}$ and $\mathrm{MBC}$, a comparative analysis of patients' age ( $\leq 50$ vs. $>50$ years), tumour grading (G1 vs. G2/G3) and nodal status (positive vs. negative) was previously performed in both groups to confirm the eligibility of patients.

The frequency tables were organised for the following parameters: p53, p21, pRb (positive vs. negative), Ki-67 (low vs. high cell proliferation) and DNA ploidy (aneuploidy vs. diploidy). p values $<5 \%$ were considered as the significance level.

\section{Results}

Table 2 illustrates the comparative study between the two groups of $\mathrm{FBC}$ and $\mathrm{MBC}$ patients in relation with immunohistochemical features and DNA ploidy. The MBC group showed a higher frequency of DNA aneuploid tumours, with statistical significance $(\mathrm{p}<0.001)$. The incidence of p21-positive (48/50) and p53-negative (48/50) neoplasms in $\mathrm{MBC}$ was also significantly higher than in the FBC group ( $p<0.001$ and $p=0.014$, respectively). $p R b$ and Ki-67 immunoexpression were quite similar between $\mathrm{MBC}$ and $\mathrm{FBC}$.

Table 3 summarizes the associations between parameters within both groups. In FBC, high-grade tumours strongly correlated with DNA aneuploidy $(\mathrm{p}<0.001)$ and showed a trend of being associated with high Ki-67 cell proliferation, which did not reach statistical significance $(\mathrm{p}=0.071)$. In $\mathrm{MBC}$, the two $\mathrm{p} 53$-positive tumours showed a DNA diploid pattern $(\mathrm{p}=0.037)$. Moreover, the G2/G3 grading tumours significantly correlated with DNA aneuploidy (88.6\% of cases; $\mathrm{p}=0.020)$, pRb-positive tumours (77.8\% of cases; $\mathrm{p}=0.035)$, and Ki-67-positive/high proliferative tumours $(74.3 \%$ of cases; $\mathrm{p}=$ $0.020)$.
Table 2. Comparison between $\mathrm{FBC}$ and $\mathrm{MBC}$ - characterization of the patient cohort by immunohistochemical features and DNA ploidy

\begin{tabular}{|c|c|c|c|c|c|}
\hline \multirow[t]{2}{*}{ Characteristics } & \multicolumn{2}{|c|}{ Female } & \multicolumn{2}{|c|}{ Male } & \multirow[t]{2}{*}{$\mathrm{p}$ value } \\
\hline & $\mathrm{n}$ & $\%$ & $\mathrm{n}$ & $\%$ & \\
\hline p53 & & & & & 0.014 \\
\hline Positive & 9 & 18 & 2 & 4 & \\
\hline Negative & 41 & 82 & 48 & 96 & \\
\hline $\mathrm{p} 21$ & & & & & $<0.001$ \\
\hline Positive & 29 & 58 & 48 & 96 & \\
\hline Negative & 21 & 42 & 2 & 4 & \\
\hline $\mathrm{pRb}$ & & & & & 0.159 \\
\hline Positive & 13 & 26 & 15 & 30 & \\
\hline Negative & 37 & 74 & 35 & 70 & \\
\hline Ki67 & & & & & 0.157 \\
\hline$\leq 10 \%$ & 25 & 50 & 18 & 36 & \\
\hline$>10 \%$ & 25 & 50 & 32 & 64 & \\
\hline DNA ploidy & & & & & $<0.001$ \\
\hline Diploid & 27 & 54 & 10 & 20 & \\
\hline Aneuploid & 23 & 46 & 40 & 80 & \\
\hline
\end{tabular}

Table 3. Correlation between variables within FBC (italics) and MBC groups

\begin{tabular}{lllclll}
\hline Variables & Grade & Ki-67 & Ploidy & p53 & p21 & pRb \\
\hline Grade & - & 0.071 & $<\mathbf{0 . 0 0 1}$ & 0.373 & 0.867 & 0.571 \\
Ki-67 & $\mathbf{0 . 0 2 0}$ & - & 0.128 & 0.145 & 0.085 & 0.500 \\
Ploidy & $\mathbf{0 . 0 2 0}$ & 0.463 & - & 0.261 & 0.145 & 0.380 \\
p53 & 0.538 & 0.595 & $\mathbf{0 . 0 3 7}$ & - & 0.176 & 0.258 \\
p21 & 0.538 & 0.595 & 0.637 & 0.921 & - & 0.268 \\
pRb & $\mathbf{0 . 0 3 5}$ & 0.074 & 0.263 & 0.309 & 0.691 & - \\
\hline
\end{tabular}

The $\chi^{2}$ test and Fisher's exact test were used. Significant associations are given in bold.

\section{Discussion}

It is well established that genetic abnormalities related to proteins that control the cell cycle, together with hormones and other growth regulators, by promoting or inhibiting cellular proliferation and apoptosis, are implicated in the tumour development and progression of both FBC and MBC [7-11, 19]. Since MBC is an uncommon entity, the biological information on its oncogenesis mechanisms has been largely extrapolated from its female counterpart. The question is: do cancer growth regulators act in a similar way in cases of FBC and MBC? 
Previous studies reported that $\mathrm{MBC}$ and $\mathrm{FBC}$ have some biological characteristics in common, but also exhibit significant differences $[1,3,20,21]$. It still remains controversial whether the development of $\mathrm{MBC}$ parallels that of FBC, and how genetic alterations affect the molecular pathogenesis and patients' management.

In our study, we selected two relatively homogeneous groups of male and female patients who had not received primary neoadjuvant therapy and did not show significant differences in pathological features, such as histological type, tumour grading and nodal status. The age of patients, while corroborating the documented occurrence of $\mathrm{MBC}$ in older patients compared with FBC [21], revealed no statistically significant difference either. The methodological approach, aiming to improve the clinicopathological and therapeutic similarity of the two groups, allowed a more reliable comparison between different features.

The main findings of the present study related with the significantly higher incidence of DNA aneuploidy, p53-negative and p21-positive tumours in MBC.

As previously reported in another study of our group [12], DNA ploidy is strongly correlated with histological grade in FBC, which also occurred in MBC. The high rates of aneuploidy in $\mathrm{MBC}$, in general associated with a poor clinical outcome [13], indicate increased genomic instability, suggesting the presence of specific chromosomal abnormalities. The differences in the DNA ploidy status between $\mathrm{FBC}$ and $\mathrm{MBC}$ were statistically significant and could reflect distinct underlying mechanisms of genetic evolution.

The reported incidence and biological impact of p53 expression are variable both in FBC and MBC $[1,2,5,6$, $13,22-26]$. In the present study, p53 positivity was low in FBC $(18 \%)$ and rare in MBC (2 cases, $4 \%)$. Despite the small number of cases, the difference is statistically significant. However, the association between 553 positivity and DNA diploidy in MBC seems surprising, possibly due to the fact that only two tumours were positive, since p53 immunoexpression is usually associated with aneuploid phenotypes and a worse prognosis [13,27].

In our study, the percentage of abnormal p21 expression (immunohistochemical negative tumours) was significantly lower in MBC than in FBC (4 and $42 \%$ of cases, respectively), which is in keeping with previous results reported by Curigliano et al. [3]. The significant difference of $\mathrm{p} 21$ expression in $\mathrm{FBC}$ and $\mathrm{MBC}$ appears to be an especially important finding, as it may be an indicator of a distinct pattern of tumorigenesis in these groups of tumours. The coexistence of high p 21 positivity ( $96 \%$ of the cases) and the lack of p53 overexpression (96\% of the cases), reflecting normal biological mechanisms, strongly suggest that alterations to the p53 signalling pathway have very little influence on MBC tumour development.

In the literature, variable expression of p21 protein and its diverse correlation with other parameters and prognosis were reported in breast cancer, which could be explained by the different methods of immunohistochemical detection and interpretation criteria used $[3,5$, $6,9,24,27-30]$. We adopted the most reported cut-off point for staining interpretation, to make the interlaboratory comparison of results easier. In this study, as in others $[6,29,30]$, p21 expression was not correlated with other cell cycle regulatory proteins, Ki-67 proliferation marker and DNA ploidy, keeping its biological role in cancer progression unclear.

Our data revealed no statistically significant differences between the two groups in relation to $\mathrm{pRb}$ expression and Ki-67 tumour proliferative activity. We found a high percentage of $\mathrm{pRb}$-negative cases, which was similar in $\mathrm{FBC}$ and $\mathrm{MBC}$ (74 and 70\%, respectively), suggesting that most tumours presented in their pRb-inactive phosphorylated form. There was a significant correlation in $\mathrm{MBC}$ between $\mathrm{pRb}$ and grade, but we have failed to previously demonstrate reported associations of $\mathrm{pRb}$ with $\mathrm{Ki}$ 67 and p53 [11,23]. The cell proliferation, as assessed by $\mathrm{Ki}-67$, correlated with tumour grade in $\mathrm{MBC}$ and showed a trend in FMC. However, in accordance with data of Pich et al. [13], it was quite similar in the two groups of breast cancers in our series.

In conclusion, our results showed that the cell cycle regulatory proteins investigated in $\mathrm{FBC}$ and $\mathrm{MBC}$ have very few similarities, suggesting the existence of independent mechanisms of tumorigenesis. In addition, the significant dissimilarities regarding DNA ploidy, p21 and p53 expression in these quite homogeneous groups of FBC and MBC point to different genomic instability and to differences in the cell cycle proliferative control, reinforcing the view of somewhat distinct pathways of tumour oncogenesis.

\footnotetext{
References

1 Muir D, Kanthan R, Kanthan SC: Male versus female breast cancers. A populationbased comparative immunohistochemical analysis. Arch Pathol Lab Med 2003;127:3641.

2 Giordano S: A review of the diagnosis and management of male breast cancer. Oncologist 2005;10:471-479.
} 
-3 Curigliano G, Colleoni M, Renne G, Mazzarol G, Gennari R, Peruzzotti G, de Braud E, Robertson C, Maiorano E, Veronesi P, Nole F, Mandala M, Ferretti G, Viale G, Goldhirsch A: Recognizing features that are dissimilar in male and female breast cancer: expression of p21Waf1 and p27Kip1 using an immunohistochemical assay. Ann Oncol 2002;13:895-902.

-4 Weiss RH: p21Wafl/Cip1 as a therapeutic target in breast and other cancers. Cancer Cell 2003;4:425-429.

5 Pellikainen MJ, Pekola TT, Ropponen KM, Kataja VV, Kellokoski JK, Eskelinen MJ, Kosma V-M: p21 ${ }^{\text {WAF1 }}$ expression in invasive breast cancer and its association with p53, AP-2, cell proliferation, and prognosis. J Clin Pathol 2003;56:214-220.

6 6 Kourea HP, Koutras AK, Scopa CD, Marangos MN, Tzoracoeleftherakis E, Koukouras D, Kalofonos HP: Expression of the cell cycle regulatory proteins $\mathrm{p} 34^{\mathrm{cdc} 2}, \mathrm{p} 21^{\text {waf1 }}$, and $\mathrm{p} 53$ in node negative invasive ductal breast carcinoma. Mol Pathol 2003;56:328-335.

-7 Haupt Y, Robles AI, Prives C, Rotter V: Deconstruction of $\mathrm{p} 53$ functions and regulation. Oncogene 2002;21:8223-8231.

8 Fan Y, Borowsky AD, Weiss RH: An antisense oligodeoxynucleotide to p21 (Wafl/ Cip1) causes apoptosis in human breast cancer cells. Mol Cancer Ther 2003;2:773-782.

-9 Bearss DJ, Lee RJ, Troyer DA, Pestell RG, Windle JJ: Differential effects of p21 WAF1/ CIP1 deficiency on MMTV-ras and MMTVmyc mammary tumor properties. Cancer Res 2002;62:2077-2084.

-10 Chen X, Danes C, Lowe M, Herliczek TW, Keyomarsi K: Activation of the estrogen-signaling pathway by p21(WAF1/CIP1) in estrogen receptor-negative breast cancer cells. J Natl Cancer Inst 2000;92:1403-1413.

-11 Ceccarelli C, Santini D, Chieco P, Taffurelli M, Gamberini M, Pileri SA, Marrano D: Retinoblastoma (RB1) gene product expression in breast carcinoma. Correlation with Ki-67 growth fraction and biopathological profile. J Clin Pathol 1998;51:818-824.
12 Pinto AE, André S, Soares J: Short-term significance of DNA ploidy and cell proliferation in breast carcinoma: a multivariate analysis of prognostic markers in a series of 308 patients. J Clin Pathol 1999;52:604-611.

13 Pich A, Margaria E, Ponti R, Geuna M: DNA ploidy and p53 expression correlate with survival and cell proliferative activity in male breast carcinoma. Hum Pathol 1996;27:676682.

14 Tavassoli FA, Devilee P (eds): World Health Organization of Tumors. Pathology and Genetics of Tumors of the Breast and Female Genital Organs. Lyon, IARC Press, 2003.

15 American Joint Committee on Cancer: Breast; in Greene FL, Page DL, Fleming ID (eds): AJCC Cancer Staging Handbook, ed 6. New York, Springer, 2002.

16 Elston CW, Ellis IO: Pathological prognostic factors in breast cancer. 1 . The value of histological grade in breast cancer: experience from a large study with long-term follow-up. Histopathology 1991;19:403-410.

$>17$ Hsu SM, Raine L, Fanger H: The use of antiavidin antibody and avidin-biotin-peroxidase complex in immunoperoxidase techniques. Am J Clin Pathol 1981;75:816-821.

18 Hedley DW, Friedlander ML, Taylor IW, Rugg CA, Musgrove EA: Method for analysis of cellular DNA content of paraffin-embedded pathological material using flow cytometry. J Histochem Cytochem 1983;31:13331335.

19 Jiang Z, Zacksenhaus E: Activation of retinoblastoma protein in mammary gland leads to ductal growth suppression, precocious differentiation, and adenocarcinoma. J Cell Biol 2002;156:185-198.

20 Wick MR, Sayadi H, Ritter JH, Hill DA, Reddy VB, Gattuso P: Low-stage carcinoma of the male breast. A histologic, immunohistochemical, and flow cytometric comparison with localized female breast carcinoma. Am J Clin Pathol 1999;111:59-69.

21 Burga AM, Fadare O, Lininger RA, Tavassoli FA: Invasive carcinomas of the male breast: a morphologic study of the distribution of histologic subtypes and metastatic patterns in 778 cases. Virchows Arch 2006; 449:507-512.

-22 André S, Fonseca I, Pinto AE, Cardoso P, Pereira T, Soares J: Male breast cancer. A reappraisal of clinical and biologic indicators of prognosis. Acta Oncol 2001;40:472-478.
23 Ioachim EE, Malamou-Mitsi V, Kamina SA, Goussia AC, Agnantis NJ: Immunohistochemical expression of $\mathrm{Bcl}-2$ protein in breast lesions: correlation with $\mathrm{Bax}, \mathrm{p} 53, \mathrm{Rb}$, C-erbB-2, EGFR and proliferation indices. Anticancer Res 2000;20:4221-4226.

24 Domagala W, Welcker M, Chosia M, Karbowniczek M, Harezga B, Bartkova J, Bartek J, Osborn M: p21/WAF1/Cip1 expression in invasive ductal breast carcinoma: relationship to 553 , proliferation rate, and survival at 5 years. Virchows Arch 2001;439:132-140.

25 Mourao Netto M, Logullo AF, Nonogaki S, Brentani RR, Brentani MM: Expression of cerbB-2, p53 and c-myc proteins in male breast carcinoma: comparison with traditional prognostic factors and survival. Braz J Med Biol Res 2001;34:887-894.

26 Wang-Rodrigues J, Cross K, Gallagher S, Djahanban M, Amstrong JM, Wiedner N, Shapiro DH: Male breast carcinoma: Correlation of ER, PR, Ki-67, Her2-neu, and p53 with treatment and survival, a study of 65 cases. Mod Pathol 2002;15:853-861.

27 O'Hanlon DM, Kiely M, MacConmara M, Al-Azzawit R, Connolly Y, Jeffers M, Keane FBV: An immunohistochemical study of p21 and $\mathrm{p} 53$ expression in primary node-positive breast carcinoma. Eur J Surg Pathol 2002;26: 103-107.

28 Göhring U-J, Bersch A, Becker M, Neuhaus W, Schöndorf T: p21 ${ }^{\text {waf }}$ correlates with DNA replication but not with prognosis in invasive breast cancer. J Clin Pathol 2001;54: 866-870.

29 Michels JJ, Duigou F, Marnay J, Henry-Amar M, Delozier T, Denoux Y, Chasle J: Flow cytometry and quantitative immunohistochemical study of cell cycle regulation proteins in invasive breast carcinoma. Prognostic significance. Cancer 2003;97:1376-1386.

30 Pinto AE, André S, Laranjeira C, Soares J: Correlations of cell cycle regulators ( $\mathrm{p} 53$, $\mathrm{p} 21, \mathrm{pRb}$ and $\mathrm{mdm} 2$ ) and c-erbB-2 with biological markers of proliferation and overall survival in breast cancer. Pathology 2005;37: 45-50. 